\title{
Fingernail length as a predisposing factor for perforations of latex gloves: a simulated clinical experiment
}

Suhail Al-Amad, ${ }^{1,2}$ Ala'a El-Saleh, ${ }^{2}$ Shorouk Elnagdy, ${ }^{2}$ Fatimah Al-Nasser ${ }^{2}$ and Sarah Alsellemi ${ }^{2}$

${ }^{1}$ College of Dental Medicine, University of Sharjah, Sharjah, United Arab Emirates (Correspondence to: S. Al-Amad: salamad@sharjah.ac.ae). ${ }^{2}$ University Dental Hospital Sharjah, Sharjah, United Arab Emirates.

\begin{abstract}
Background: Concerns have been raised over the integrity of gloves and the longevity of their protective barrier function. Aims: This study aimed to assess the effect of clinicians' fingernail length as a predisposing factor for perforation of latex gloves.

Methods: We assessed 2006 latex examination gloves for perforations using the water inflation method after being used by 6 senior dental students who had fingernail lengths ranging from o to $3 \mathrm{~mm}$. Four simulated clinical procedures representing a variety of hand movements were used for this purpose and were repeated 30 times, followed by a water leakage assessment test. Data were analysed using the $\chi^{2}$ test, analysis of variance and logistic regression.

Results: Leakage was detected in 222 (11.1\%) gloves, and was most frequent with longer fingernails (odds ratio =1.431, 95\% confidence interval 1.249-1.640; $P<0.001$ ). This was independent from the simulated clinical procedure. Most perforations were over the index fingers and thumbs $(63.5 \%$ and $24.3 \%$, respectively; $P<0.001)$. The simulated procedures with most perforations were wiping the scaler tip with gauze $(20.8 \%)$ and placing the chamfer bur (15.3\%). The procedure with the fewest perforations was placing the triple way syringe (3.5\%).

Conclusion: The length of the clinicians' fingernails significantly compromises the integrity of latex gloves. Maintaining short fingernails is important in reducing the risk of damaging latex gloves intraoperatively, and hence maintaining the barrier function of the gloves.

Keywords: dentistry, fingernails, gloves, infection control, perforation.

Citation: Al-Amad S; El-Saleh A; Elnagdy S; Al-Nasser F; Alsellemi S. Fingernail length as a predisposing factor for perforations of latex gloves: a simulated clinical experiment. East Mediterr Health J. 2019;25(12):872-877. https://doi.org/10.26719/emhj.19.052

Received: 24/12/17; accepted: 20/05/18

Copyright $@$ World Health Organization (WHO) 2019. Some rights reserved. This work is available under the CC BY-NC-SA 3.0 IGO license (https:// creativecommons.org/licenses/by-nc-sa/3.o/igo).
\end{abstract}

\section{Introduction}

Health care workers rely on latex gloves as an essential part of their personal protective equipment. Gloves are a physical barrier that prevents contact of dental healthcare workers' skin with bloodborne pathogenic microorganisms from patients' oral cavities and biological fluids (1). Such pathogens include hepatitis $C$ virus, which has been detected on the oral mucosal surface (2) and in saliva of infected patients (3), and human papilloma virus and Staphylococcus aureus, which have been cultured from clinicians' gloves after treatment of patients $(4,5)$.

The integrity of the gloves in medical and dental care is important in preventing the transmission of pathogenic microorganisms from patients to health care workers and vice versa. However, several researchers have raised concerns over this integrity (6-8). For example, Patel et al. found that $0-3 \%$ of unused gloves have pre-existing punctures (9), while Murray et al. found that 1.95-5.3\% of gloves had defects following routine dental practice (10). The integrity of gloves as a physical barrier has been linked to a number of factors, such as the material of the gloves and their latex content, as well as the duration and nature of the clinical procedures $(10-15)$. The role of fingernails in compromising glove integrity has not been previously assessed.
The aim of this study was to assess the effect of fingernail length on the rate of perforation of latex gloves when used in several simulated clinical procedures.

\section{Methods}

This simulated clinical experiment of 2006 nonpowdered latex examination gloves took place at the University Dental Hospital Sharjah, United Arab Emirates, between January and April 2017. All gloves belonged to the same commercial brand and were used after visual assessment for gross manufacturer's defects. Gloves with defects were excluded.

Four simulated clinical procedures were undertaken by 6 female final-year dental students who were fully acquainted with each of the procedures. The students were oriented and calibrated during a pilot phase of the study to ensure homogeneity of conduct of the simulated clinical procedures. The procedures were selected based on common hand movements during regular dental practice: 1) placing a triple-way syringe into a hand piece and removing it; 2 ) placing a local anaesthesia needle in a syringe and removing it; 3) placing a chamfer bur into a hand piece and removing it; and 4) wiping a scaler tip with gauze. Each of the simulated procedures was consecutively repeated 30 times. 
Fingernail lengths were measured before wearing the gloves using a calibrated periodontal probe and were set at $0,1,2$ and $3 \mathrm{~mm}$, and the nails were filed to smoothen sharp edges. A periodontal probe is a stainless steel instrument that is commonly used to measure the periodontal (gingival) pocket depth. In this study, the probe was used to measure the length of each fingernail by inserting the probe underneath the fingernail, and measure the free edge from the hyponychium to the end of the free edge. Each of the dental students (operators) undertook all the simulated clinical procedures with 2 lengths of their fingernails. Three operators performed the 4 procedures with fingernails of 0 and $1 \mathrm{~mm}$, and the other 3 performed the same procedures with fingernails of 2 and $3 \mathrm{~mm}$.

Immediately after completing the 30 rounds of simulated clinical procedures, the gloves were gently removed from the hands and a modified water inflation method was used to assess integrity of the gloves by filling each glove with $330 \mathrm{ml}$ tap water (10). The gloves were then closed with a knot, laid down on tissue paper and covered with a weight of $0.33 \mathrm{~kg}$ on a wooden plate, in order to induce leakage if there were microperforations. The integrity of each glove was visually assessed by observing any water leakage for 3 minutes.

IBMSPSS/PASW version was used for data processing and analysis. The $\chi^{2}$ test and independent samples t-test were used to assess the association between glove integrity as a dependent variable (perforated versus intact) and fingernail length both as a categorical and continuous variable. One-way analysis of variance was used to compare the mean fingernail lengths over different fingers. Logistic regression analysis was used to assess the association between glove integrity as a dependent variable and fingernail length, after controlling for the 4 clinical procedures. Odds ratios (ORs) with $95 \%$ confidence intervals (CIs) were calculated, and $P \leq 0.05$ was considered significant.

\section{Results}

Two hundred and twenty-two gloves (11.1\%) showed perforations following the simulated clinical procedures (Table 1). More than two thirds of perforations were associated with fingernail lengths of $2 \mathrm{~mm}$ and $3 \mathrm{~mm}$. The average length of the fingernails was $1.80 \mathrm{~mm}$ and $1.43 \mathrm{~mm}$ for the perforated and intact gloves, respectively, which was a statistically significant difference $(P<0.0001$, based on independent samples t-test).

Table 2 shows the rate of perforations for each of the 4 simulated clinical procedures. The simulated procedures with most perforations were wiping the scaler tip with gauze $(20.8 \%)$ and placing the chamfer bur $(15.3 \%)$. The procedure with the fewest perforations was placing the triple way syringe $(3.5 \%)(P<0.0001)$.

Most perforations were observed over the index fingers $(63.5 \%)$ and thumbs (24.3\%) (Table 3). However, there was no significant difference in the average fingernail length between the different fingers.

Logistic regression showed that fingernail length had a positive association with glove perforation, with an OR of 1.43, regardless of which simulated procedure was used (Table 4).

\section{Discussion}

Gloves are an important physical protective barrier between clinicians' hands and patients' biological fluids, and the integrity of this barrier must be maintained throughout the clinical procedure. Several authors have raised concerns about the integrity of gloves before and after clinical use and have reported various rates of perforation. Patel et al. found that $0-3 \%$ of unused gloves had perforations as a result of manufacturers' defects (9). Other investigators assessed the integrity of gloves after clinical procedures and reported considerable diversity in the rate of perforations, from $1.9 \%$ (10) to $41 \%$ (15). The compromised integrity of examination and surgical gloves has been linked to a number of factors, such as: the

\begin{tabular}{|c|c|c|c|c|c|}
\hline & \multicolumn{4}{|c|}{ Fingernail length (mm) } & \multirow[t]{2}{*}{ Total } \\
\hline & $\mathbf{0}$ & 1.0 & 2.0 & 3.0 & \\
\hline \multicolumn{6}{|c|}{ Perforated gloves } \\
\hline$n$ & 43 & 36 & 65 & 78 & 222 \\
\hline$\%$ & $19.4 \%$ & $16.2 \%$ & $29.3 \%^{*}$ & $35.1 \%^{*}$ & $100.0 \%$ \\
\hline \multicolumn{6}{|c|}{ Intact gloves } \\
\hline$n$ & 464 & 470 & 465 & 385 & 1784 \\
\hline$\%$ & $26.0 \%$ & $26.3 \%$ & $26.1 \%$ & $21.6 \%$ & $100.0 \%$ \\
\hline \multicolumn{6}{|c|}{ Total } \\
\hline$n$ & 507 & 506 & 530 & 463 & 2006 \\
\hline$\%$ & $25.3 \%$ & $25.2 \%$ & $26.4 \%$ & $23.1 \%$ & $100.0 \%$ \\
\hline
\end{tabular}

${ }^{*} \mathrm{P}<0.001$ based on $\chi 2$ test. Pearson $\chi 2$ value $=27.962$. 


\begin{tabular}{|c|c|c|c|c|c|}
\hline & \multicolumn{4}{|c|}{ Simulated clinical procedure* } & \multirow[t]{2}{*}{ Total } \\
\hline & $\begin{array}{l}\text { Wiping the scaler } \\
\text { tip }\end{array}$ & $\begin{array}{l}\text { Placing and } \\
\text { removing a } \\
\text { chamfer bur }\end{array}$ & $\begin{array}{c}\text { Screwing and } \\
\text { unscrewing a } \\
\text { local anaesthesia } \\
\text { needle }\end{array}$ & $\begin{array}{l}\text { Placing and } \\
\text { removing a triple } \\
\text { way syringe }\end{array}$ & \\
\hline \multicolumn{6}{|c|}{ Perforated gloves } \\
\hline$n$ & 96 & 81 & 27 & 18 & 222 \\
\hline$\%$ & $20.8 \%$ & $15.3 \%$ & $5.3 \%$ & $3.5 \%$ & $11.1 \%$ \\
\hline \multicolumn{6}{|c|}{ Intact gloves } \\
\hline$n$ & 365 & 449 & 478 & 492 & 1784 \\
\hline$\%$ & $79.2 \%$ & $84.7 \%$ & $94.7 \%$ & $96.5 \%$ & $88.9 \%$ \\
\hline \multicolumn{6}{|c|}{ Total } \\
\hline$n$ & 461 & 530 & 505 & 510 & 2006 \\
\hline$\%$ & $23.0 \%$ & $26.4 \%$ & $25.2 \%$ & $25.4 \%$ & $100.0 \%$ \\
\hline
\end{tabular}

${ }^{*} \mathrm{P}<0.001$ based on $\chi 2$ test. Pearson $\chi 2$ value $=100.397$.

material of the glove, being latex and non-latex (i.e. nitrile or vinyl) (9); concentration of latex in the glove (12); duration for which gloves were used $(11,13)$; and the nature of clinical hand manipulation related to the clinical specialty $(9,14,15)$. The effect of clinicians' fingernail length as a predisposing factor for latex glove perforation following clinical procedures has not been previously investigated.

To investigate this effect, we used senior female dental students whose fingernails were set to 4 predetermined lengths between 0 and $3 \mathrm{~mm}$. Fingernails were measured using a calibrated periodontal probe, and the nails were filed to smoothen any sharp edges. The students were then trained and calibrated to undertake 4 simulated clinical procedures. The procedures were selected based on possible hand movements during clinical dental duties, which included the use of fingers to screw and unscrew an object (i.e. a local anaesthesia needle), to push a sharp object (i.e. placing a chamfer bur into the hand piece), to push a blunt object (i.e. placing a triple syringe into the air/water hand piece), and to wipe a sharp object (i.e. wiping a scaler tip). The 4 procedures were equally performed by all students and with all fingernail lengths.

The effect of hand movements on the rate of glove perforation was investigated by Solda et al. who showed a significantly higher rates of perforations in traumatic emergency procedures compared to nontraumatic ones (16). Goldman et al. investigated the rate of perforations after using orthopaedic rotatory sharp instruments, and showed that more than half of surgical gloves caught in those instruments demonstrated perforations (17).

In order to eliminate the possibility of gloves perforations being caused by external factors, we conducted repeated and standardized simulated clinical procedures that simulated the hand movements without themselves perforating the gloves. The duration of hand manipulations was set at 30 repeats.

Our results showed that $11.1 \%$ of latex gloves had perforations following repeated simulated clinical procedures. The average length of fingernails was 1.80 and $1.43 \mathrm{~mm}$ for the perforated and intact gloves, respectively. Regardless of the simulated clinical procedure, the fingernail length was a significant factor in causing glove perforations. Most of the glove damage was associated with the action of wiping the scaler tip with a piece of gauze, followed by placing a chamfer bur into the hand piece, while the least leakage was associated with placement of the triple syringe. These results infer that greater risk of perforation is associated with physical manipulation of sharp dental instruments (scaler tip and chamfer bur) compared with blunt ones.

Our results also showed that most glove perforations were over the index fingers (63.5\%) and thumbs (24.3\%). This can be explained by the fact that most hand movements in dental practice are dependent on these fingers, over which the gloves will have the heaviest friction. This finding is similar to that reported by Phelan and Wong (18). However, in other studies, perforation rates over the thumbs and index fingers combined

Table 3 The greatest perforations were associated with the index finger

\begin{tabular}{lcc} 
Site of perforation & Rate of perforation, $\mathbf{n}(\%)$ & Average length of fingernail (mm) * \\
Thumb & $54(24.3 \%)$ & 1.52 \\
Index & $141(63.5 \%)$ & 1.91 \\
Others & $27(12.2 \%)$ & 1.77 \\
Total & $222(100 \%)$ & \\
\hline
\end{tabular}

${ }^{*} \mathrm{P}=0.293 . \mathrm{F}=3.028$. Based on analysis of variance. 


\begin{tabular}{|c|c|c|c|}
\hline Variable & Odds ratio & & \\
\hline Fingernail length $(\mathrm{mm})$ & 1.431 & 1.249 & 1.640 \\
\hline Wiping the scaler tip* & 7.752 & 4.585 & 13.107 \\
\hline Putting and removing the chamfer bur* & 4.978 & 2.934 & 8.447 \\
\hline Putting and removing the local anesthesia needle* & 1.545 & 0.838 & 2.848 \\
\hline
\end{tabular}

*Reference group is the triple way syringe. $C I=$ confidence interval.

ranged from $41 \%(14)$ to $60 \%(9,19)$. Despite this diversity, all reports are in agreement that these 2 sites account for the greatest incidence of perforations. The average length of fingernails in the gloves perforated over the thumbs and index fingers were 1.52 and $1.91 \mathrm{~mm}$, respectively, compared with $1.43 \mathrm{~mm}$ for the intact gloves. This indicates a greater effect of the length of index fingernail on glove; however, this difference was not significant.

The method used in this study to detect leakage through water inflation is universally accepted (20). However different studies adopted various ways to assess this leakage visually. For example, Pieper et al. applied pressure to the wrist area of the water-filled gloves (21), while Murray et al. assessed the leakage from a suspended water-filled glove (10).

The high prevalence of glove perforation detected by this method raises concerns over the effectiveness of latex gloves in protecting clinicians' hands. A similar concern was reported by 2 Cochrane reviews that found that double gloving significantly reduces perforations of the innermost gloves and percutaneous exposure of the clinicians' hands $(22,23)$. Further studies looking into the cost-effectiveness of using double, or even triple gloves are needed in order to modify the currently accepted universal precautions with regards to glove wearing.

Our study adds to current knowledge that fingernail length is a significant factor in damaging gloves during clinical procedures and undermining their integrity as a physical barrier. The use of simulated rather than actual clinical procedures could have concentrated manipulations to the primary two fingers (index and thumb) with little involvement of the other fingers, which could limit our ability to generalize our results. Another possible limitation was that only 1 brand of latex gloves was used, and it is possible that other brands with different latex content would have produced different results. Moreover, microperforations could have been present as manufacturer's defects that were not visually detectable, and these might have increased the rate of perforations following the water leakage test.

Nevertheless, our findings shed light on an inherent factor related to clinicians, rather than clinical procedures or the material composition of the gloves material, as a significant factor in causing glove perforations. It is therefore recommended that clinicians maintain fingernail lengths $<1 \mathrm{~mm}$ to reduce the likelihood of damage to gloves.

\section{Acknowledgements}

The authors are thankful to Professor Manal Awad for her assistance in the statistical analysis and for Noor Al Mokhtar and Ghada Al Sakri for their assistance in conducting this study.

Funding: University of Sharjah College of Dental Medicine.

Competing interests: None declared.

\section{Longueur de l'ongle comme facteur prédisposant à la perforation des gants latex : expérience clinique simulée}

\section{Résumé}

Contexte : L'intégrité des gants et la longévité de leur protection en tant que barrière ont suscité des préoccupations.

Objectif : La présente étude visait à évaluer l'effet de la longueur de l'ongle du clinicien en tant que facteur prédisposant à la perforation des gants latex.

Méthodes : 2006 gants d'examen latex ont été évalués pour les perforations à l'aide de la méthode de gonflage à l'eau après utilisation par six étudiants de dernière année de faculté de médecine dentaire dont la longueur des ongles variait de $0 \mathrm{~mm}$ à $3 \mathrm{~mm}$. Quatre procédures cliniques simulées représentant une variété de mouvements de la main ont été utilisées à cette fin et ont été répétées 30 fois, suivies d'un test d'évaluation de fuite d'eau. Les données ont été analysées à l'aide du test du $\chi^{2}$, de l'analyse de variance et de la régression logistique.

Résultats : Des fuites ont été détectées dans $222(11,1 \%)$ des gants et étaient plus fréquentes avec des ongles plus longs (odds ratio $=1,431$, intervalle de confiance à $95 \%: 1,249-1,640 ; p<0,001$ ), indépendamment de la procédure 
clinique simulée. La grande majorité des perforations se situaient sur le bout de l'index et du pouce $(63,5 \%$ et $24,3 \%$ respectivement ; $p<0,001)$. L'essuyage de la pointe du détartreur avec de la gaze $(43,2 \%)$ et le placement de la fraise à chanfreiner $(36,5 \%)$ représentaient les procédures simulées donnant lieu à la plupart des perforations tandis que l'installation de la seringue à trois voies $(8,1 \%)$ était celle ayant donné lieu au moindre nombre de perforations.

Conclusion : La longueur des ongles des cliniciens est un facteur important qui compromet l'intégrité des gants latex. Il importe de garder les ongles courts pour réduire le risque d'endommager les gants latex pendant l'opération, et donc maintenir l'effet barrière des gants.

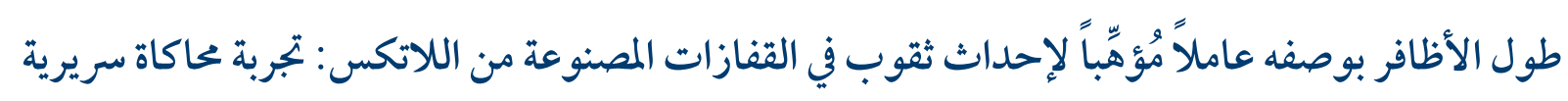
سهيل العمد، آلاء الصالح، شروق النجدي، فاطمة الناصر، ساره السلمي

$$
\text { الخلالاصة ألخية: أثيرت خخاوف بشأن سلامة القفازات وطول مدة الحماية التي توفرها القفاز ات بو صفها حائلاً. }
$$

الأهداف: هدفت هذه الدر اسة إلى تقييم تأثير طول أظافر الأطباء السريريين بو صفه أحد العوامل المسببة لانثقاب القفازات المصنوعة من اللاتكس.

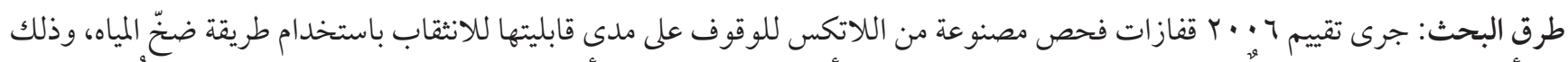

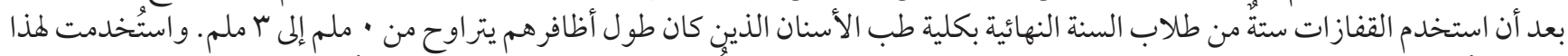

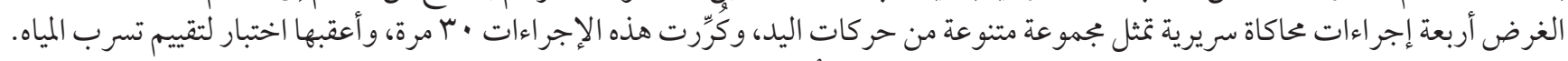

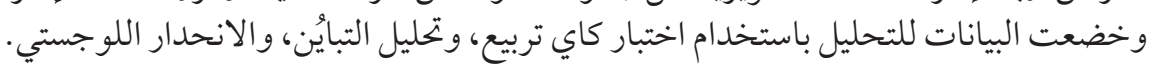

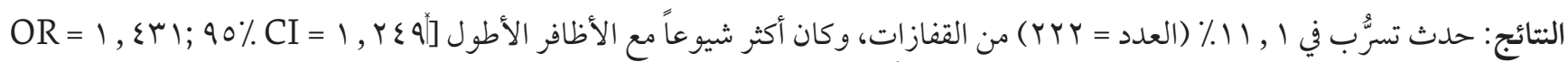

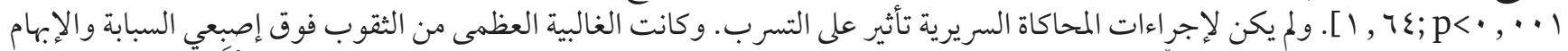

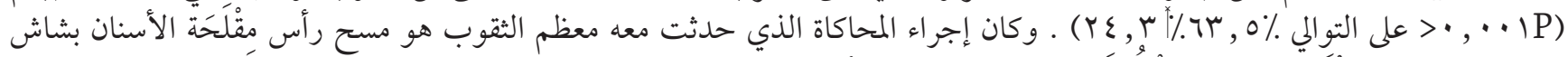

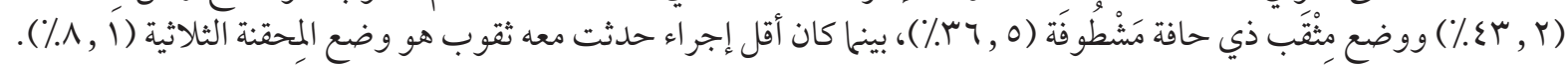

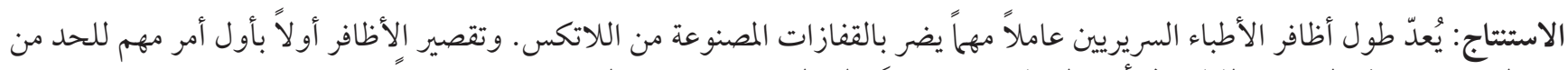

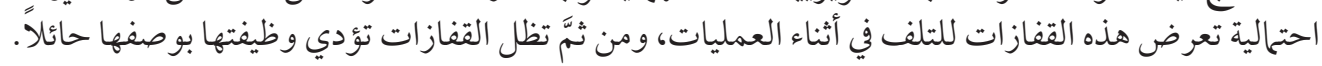

\section{References}

1. Hayden MK, Blom DW, Lyle EA, Moore CG, Weinstein RA. Risk of hand or glove contamination after contact with patients colonized with vancomycin-resistant enterococcus or the colonized patients' environment. Infect Control Hosp Epidemiol. 2008 Feb;29(2):149-54. http://dx.doi.org/10.1086/524331. PMID:18179370

2. Carrozzo M, Quadri R, Latorre P, Pentenero M, Paganin S, Bertolusso G, et al. Molecular evidence that hepatitis C virus replicates in the oral mucosa. J Hepatol 2002 Sep;37(3):364-9. PMID:12175632

3. Hermida M, Ferreiro MC, Barral S, Laredo R, Castro A, Diz Dios P. Detection of HCV RNA in saliva of patients with hepatitis C virus infection by using a highly sensitive test. J Virol Methods. 2002 Mar;101(1-2):29-35. PMID:11849681

4. Negrini Tde C, Duque C, de Oliveira AC, Hebling J, Spolidorio LC, Spolidorio DM. Staphylococcus aureus contamination in a pediatric dental clinic. J Clin Pediatr Dent. 2009 Fall;34(1):13-8. PMID:19953803

5. Ilmarinen T, Auvinen E, Hiltunen-Back E, Ranki A, Aaltonen LM, Pitkäranta A. Transmission of human papillomavirus DNA from patient to surgical masks, gloves and oral mucosa of medical personnel during treatment of laryngeal papillomas and genital warts. Eur Arch Otorhinolaryngol. 2012 Nov;269(11):2367-71. http://dx.doi.org/10.1007/s00405-012-2049-9. PMID:22588197

6. Tenorio AR, Badri SM, Sahgal NB, Hota B, Matushek M, Hayden MK, et al. Effectiveness of gloves in the prevention of hand carriage of vancomycin-resistant enterococcus species by health care workers after patient care. Clin Infect Dis. 2001 Mar 1;32(5):826-9. http://dx.doi.org/10.1086/319214. PMID:11229854

7. Picheansanthian W, Chotibang J. Glove utilization in the prevention of cross transmission: a systematic review. JBI Database System Rev Implement Rep. 2015 May 15;13(4):188-230. http://dx.doi.org/10.11124/jbisrir-2015-1817 PMID:26447080

8. Neal JG, Jackson EM, Suber F, Edlich RF. Latex glove penetration by pathogens: a review of the literature. J Long Term Eff Med Implants. 1998;8(3-4):233-40. PMID:10186969

9. Patel HB, Fleming GJ, Burke FJ. A preliminary report on the incidence of pre-existing pinhole defects in nitrile dental gloves. Br Dent J. 2003 Nov 8;195(9):509-12. http://dx.doli.org/10.1038/sj.bdj.4810667 PMID:14610561

10. Murray CA, Burke FJ, McHugh S. An assessment of the incidence of punctures in latex and non-latex dental examination gloves in routine clinical practice. Br Dent J. 2001 Apr 14;190(7):377-80. http://dxdoi.org/10.1038/sj.bdj.4800978a PMID:11338041

11. Korniewicz DM, Garzon L, Seltzer J, Feinleib M. Failure rates in nonlatex surgical gloves. Am J Infect Control. 2004 Aug;32(5):268-73. http://dx.doi.org/10.1016/j.ajic.2003.12.005 PMID:15292890 
12. Muto CA, Sistrom MG, Strain BA, Farr BM. Glove leakage rates as a function of latex content and brand: caveat emptor. Arch Surg. 2000 Aug;135(8):982-5. PMID:10922263

13. Partecke LI, Goerdt AM, Langner I, Jaeger B, Assadian O, Heidecke CD, et al. Incidence of microperforation for surgical gloves depends on duration of wear. Infect Control Hosp Epidemiol. 2009 May;30(5):409-14. http://dx.doi.org/10.1086/597062 PMID:19335225

14. Taghavi Zenouz A, Mahdipour M, Pakravan R, Yazdani J, Nezafati S, Mesgarzaded AH, et al. Evaluation of glove damage during dental procedures among dental specialists in Tabriz. J Dent Res Dent Clin Dent Prospects. 2007 Summer;1(2):82-5. http://dx.doi. org/10.5681/joddd.2007.014 PMID:23277839

15. Bekele A, Makonnen N, Tesfaye L, Taye M. Incidence and patterns of surgical glove perforations: experience from Addis Ababa, Ethiopia. BMC Surg. 2017 Mar 20;17(1):26. http://dx.doi.org/10.1186/s12893-017-0228-8 PMID:2832037

16. SoldáI SC, Assef JC, Parreira III JG, Perlingeiro JAG, Candelária PAP, Cury MP, et al. Undetected perforations of surgical gloves during emergency procedures. Rev Assoc Med Bras. 2009 Sep-Oct;55(5):597-600. http://www.scielo.br/scielo.php?pid=So104-42 302009000500026\&script=sci_arttext\&tlng=en

17. Goldman AH, Haug E, Owen JR, Wayne JS, Golladay GJ. High risk of surgical glove perforation from surgical rotatory instruments. Clinical Orthopaedics and Related Research. 2016 Nov;474(11):2513-7. http://dx.doi.org/10.1007/s11999-016-4948-3 PMID:27339122

18. Phelan RN, Wong WK. Integrity of disposable nitrile exam gloves exposed to simulated movement. J Occup Environ Hyg. 2011 May;8(5):289-99. http://dx.doi.org/10.1080/15459624.2011.569285 PMID:21476169

19. Albin MS, Bunegin L, Duke ES, Ritter RR, Page CP. Anatomy of a defective barrier: sequential glove leak detection in a surgical and dental environment. Crit Care Med. 1992 Feb;20(2):170-84. PMID:1737454

20. Opinion of the Scientific Committee on Medicinal Products and Medical Devices on the protection offered by natural rubber latex medical devices (medical gloves and condoms) against transmissible diseases. Brussels: European Commission; 2003 (http:// ec.europa.eu/health/archive/ph_risk/committees/scmp/documents/out48_en.pdf, accessed 8 June 2019).

21. Pieper SP, Schimmele SR, Johnson JA, Harper JL. A prospective study of the efficacy of various gloving techniques in the application of Erich arch bars. J Oral Maxillofac Surg. 1995 Oct;53(10):1174-6. PMID:7562171

22. Tanner J, Parkinson H. Double gloving to reduce surgical cross-infection. Cochrane Database Syst Rev. 2006 Jul 19;(3):CDoo3087. http://dx.doi.org/10.1002/14651858.CD003087 PMID:12137673

23. Mischke C, Verbeek JH, Saarto A, Lavoie MC, Pahwa M, Ijaz S. Gloves, extra gloves or special types of gloves for preventing percutaneous exposure injuries in healthcare personnel. Cochrane Database Syst Rev. 2014 Mar 7;(3):CDoo9573. http://dx.doi. org/10.1002/14651858.CD009573 PMID:24610769 